\title{
PENGARUH MATA KULIAH KOMUNIKASI BISNIS DAN MOTIVASI BERWIRAUSAHA TERHADAP MINAT BERWIRAUSAHA MAHASISWA PROGRAM STUDI PENDIDIKAN TATA NIAGA 2013 UNIVERSITAS NEGERI MEDAN
}

\author{
Irwansyah 1)*, Pebi Ramadhan Damanik ${ }^{2)}$ \\ 1) Pendidikan Tata Niaga, Fakultas Ekonomi, Universitas Negeri Medan \\ 2) Pendidikan Tata Niaga, Fakultas Ekonomi, Universitas Negeri Medan \\ *Penulis korespondensi: irwansyahkfr@gmail.com
}

\begin{abstract}
Masalah dalam penelitian ini adalah apakah ada pengaruh yang positif dan signifikan antara Mata Kuliah Komunikasi Binsis dan Motivasi Berwirausaha terhadap Minat Berwirausaha mahasiswa Pendidikan Tataniaga Fakultas Ekonomi Unimed Stambuk 2013. Penelitian ini dilaksanakan di Fakultas Ekonomi Unimed yang beralamat di Jl. Willem Iskandar, Pasar V Medan Estate. Jenis penelitian ini adalah expost facto. Populasi dalam penelitian ini adalah seluruh mahasiswa Pendidikan Tataniaga yang berjumlah 108 orang. Sampel penelitian ini adalah 81 mahasiswa yang diambil dengan menggunakan teknik pengambilan sampel secara Random sampling. Teknik pengumpulan data dilakukan dengan cara observasi, wawancara, dan angket. Untuk uji instrument peneliti menggunakan uji validitas uji realibilitas. Untuk menganalisis data penulis menggunakan persamaan regresi berganda dan untuk menguji hipotesis dengan rumus uji $t$ dan uji f serta koefisien determinasi ( ). Berdasarkan hasil analisis regresi linear berganda diperoleh persamaan garis secara linear Hasil analisis uji $\mathrm{t}$ untuk variabel mata kuliah komunikasi bisnis (X1) diperoleh nilai > (6,846>1,664) Dengan demikian, maka hipotesis pertama diterima yang berarti ada pengaruh positif dan signifikan antara nilai mata kuliah komunikasi bisnis(X1) terhadap minat berwirausaha (Y). Untuk variabel motivasi berwirausaha (X2) diperoleh nilai $<(0,619<1,664)$, dengan demikian, maka hipotesis kedua ditolak yang berarti tidak ada pengaruh positif dan signifikan antara motivasi berwirausaha (X2) terhadap minat berwirausaha (Y). Berdasarkan uji f diperoleh bahwa $(40,501>3,11)$. Dengan demikian, maka hipotesis ketiga diterima yang berarti ada ada pengaruh yang positif dan signifikan antara mata kuliah komunikasi bisnis dan motivasi berwirausaha terhadap minat berwirausaha mahasiswa Pendidikan Tataniaga Fakultas Ekonomi Unimed Stambuk 2013.
\end{abstract}

Kata Kunci :komunikasi bisnis, motivasi berwirausaha, minat berwirausaha 


\section{PENDAHULUAN}

Krisis ekonomi mengakibatkan banyak nya jumlah pengangguran di indonesia. Banyak perusahaan mengalami kesulitan keuangan sehingga merampingkan struktur organisasinya dengan cara memutuskan hubungan kerja dengan para karyawannya, bahkan tidak sedikit pula perusahaan yang bangkrut karena tidak sanggup memenuhi tingginya biaya produksi.

Sebagian besar pendorong perubahan, inovasi dan kemajuan suatu negara adalah para wirausahawan atau pebisnis. Kewirahusaaan merupakan persoalan penting dadlam perekonomian suatu bangsa yang sedang membangun. Kemajuan atau kemunduran ekonomi suatu bangsa ditentukan oleh keberadaan dan peranan dari kelompok entrepreneur. Karir kewirausahaan dapat mendukung kesejahteraan masyrakat yang menghasilkan imbalan finasial yang nyata (Yohnson dalam Adeline,2011:11),

Semakin maju suatu negara semakin banyak orang yang terdidik, dan banyak pula orang yang menganggur karena sempitnya lapangan pekerjaan. Hal ini menunjukkan semakin pentingnya dunia entrepreneur di dalam perekonomian suatu negara. Pembangunan akan lebih berhasil jika ditunjang oleh para entrepreneur yang dapat membuka lapangan kerja karena kemampuan pemerintah

sangat terbatas. Pemerintah tidak akan mampu menggarap semua pembangunan karena sangat banyak membutuhkan anggaran belanja, personalia, dan pengawasan. Sehingga, lapangan yang mampu pemerintah siapkan pun sangatlah terbatas dan sulit untuk memenuhi seluruh masyarakat di Indonesia.

Kewirausahaan (entrepreneurhip) merupakan persoalan penting di dalam perekonomian suatu bangsa yang sedang berkembang. Kemajuan atau kemunduran ekonomi suatu bangsa sangat ditentukan oleh keberadaan dan peranan dari kelompok wirausahawan ini, (Rachbini,2002). menyatakan bahwa seluruh proses perubahan ekonomi pada akhirnya tergantung dari orang yang menyebabkan timbulnya perubahan tersebut yakni sang "entrepreneur". Kebanyakan perusahaan yang sedang tumbuh dan yang bersifat inovatif menunjukan suatu jiwa (spirit) entrepreneur. Korporasi-korporasi berupaya untuk mendorong para manajer mereka menjadi orang-orang yang berjiwa entrepreneur, universitas-universitas sedang mengembangkan programprogram entrepreneurhip, dan para
NIAGAWAN Vol 7 No 1 Maret 2018 entrepreneur individual menimbulkan perubahan-perubahan dramatik dalam masyarakat. Jadi, kewirausahaan merupakan suatu kemampuan dalam menciptakan nilai tambah di pasar melalui proses sumber daya dengan cara-cara baru dan berbeda (Suryana, 2006). Seorang wirausahawan adalah seorang yang memiliki keahlian untuk menjual, mulai dari menawarkan ide hingga komoditas baik berupa produk atau jasa. Dengan kreativitasnya, wirausahawan mampu beradaptasi dengan berbagai situasi dan kondisi lingkungan. Sebagai pelaku bisnis, wirausahawan harus mengetahui dengan baik manajemen penjualan, gaya dan fungsi manajemen. Untuk berhasil, ia harus mampu berkomunikasi dan menguasai beberapa elemen kecakapan manajerial, serta mengetahui teknik menjual yang strategis mulai dari pengetahuan tentang produk, ciri khas produk dan daya saing produk terhadap produk sejenis.

Didalam dunia bisnis tidak semata mata hanya mengandalkan modal saja, didunia bisnis diperlukan berbagai keahlian sehingga bsinis dapat berjalan dengan baik,salah satunya adalah komunikasi yang baik, , komunikasi adalah sesuatu hal dasar yang selalu dibutuhkan dan dilakukan oleh setiap insan manusia, karena berkomunikasi merupakan dasar interaksi antar manusia untuk memperoleh kesepakatan dan kesepahaman yang dibangun untuk mencapai suatu tujuan yang maksimal diantara kedua nya, dalam menjalankan suatu usaha seseorang harus mampu membangun komunikasi secara baik agar terjalin keakraban diantara para pengusaha Di Universitas Negeri Medan yang lebih tepat nya di Fakultas Ekonomi Prodi pendidikan Tata Niaga terdapat berbagai mata kuliah yang menyangkut tentang bisnis, dan kewirausahaan. Maka dari itu penulis berniat menyinggung salah satu mata kuliah yang ada hubungan nya dengan berwirausaha, disini penulis mengambil mata kuliah komunikasi bisnis, mata kuliah ini mengandung materi untuk menumbuhkan jiwa berbsinis dan berwirausaha mahasiswa, di mata kuliah ini mahasiswa diajarkan bagaimana berkomunikasi dengan baik, komunikasi merupakan hal yang sangat penting dalam berwirausaha, suatu bisnis atau usaha apabila dapat berkomunikasi dengan baik pasti usaha tersebut dapat berjalan dengan baik.

Komunikasi Bisnis sebagai salah satu mata kuliah di Program Studi Pendidikan Tata Niaga, Fakultas Ekonomi UNIMED diharapkan mampu memberikan pengetahuan kepada mahasiswa 
untuk memiliki komunikasi yang baik, baik dalam kehidupan sehari hari maupun dalam bidang berwirausaha ataupun bisnis. Pada mata kuliah Komunikasi Bisnis, terdapat materi yang berhubungan dengan bagaimana melakukan komunikasi yang baik, bagaimana menjalin komunikasi yang baik sesama para pengusaha, bagaimana cara mengelola komunikasi yang baik agar terjalin kerjasama yang baik. Dengan termuatnya materi tersebut, maka akan memberikan pengalaman belajar pada mahasiswa dalam menanggapi proses komunikasi yang baik untuk melakukan suatu kegiatan usaha maupun suatu kegiatan bisnis lain nya, sehingga mahasiswa dapat mengatur komunikasinya dengan baik.

\section{TINJAUAN PUSTAKA}

\section{Pengertian Komunikasi Bisnis}

Komunikasi merupakan hal yang sangat fundamental dalam kehidupan. Peristiwa komunikasi bisa terjadi dimana-mana. Misalnya, menyalakan televisi dengan menekan tombol listrik (engineering communication), dua ekor burung yang saling bercengkrama (animal communication), hubungan antar sel pada saat makhluk hidup bernafas (cell communication), dan komunikasi antar manusia (human communication).

$$
\text { Menurut Purwanto (2006:4), }
$$

Komunikasi bisnis adalah komunikasi yang digunakan dalam dunia bisnis, termasuk berbagai bentuk komunikasi, baik komunikasi verbal atau komunikasi non-verbal untuk mencapai tujuan tertentu. Pada dasarnya bisnis komunikasi dibagi menjadi dua hal: verbal dan non-verbal.

$\begin{array}{ccc}\begin{array}{c}\text { Menurut } \\ \text { Bimstreet dan Baty dalam } \\ \text { communication }\end{array} & \text { (Djoko }\end{array}$

Purwanto2013:04) :princples and Method, komunikasi adalah suatu proses pertukaran informasi antar individu melalui sistem yang biasa (lazim), baik dengan simbol-simbol, sinyal-sinyal maupun proses pengiriman dan penerimaan pesan

Menurut Djoko Purwanto(2013: Komunikasi bisnis adalah komunikasi yang digunakan dalam dunia bisnis, mencakup berbagai macam bentuk komunikasi baik komunikasi verbal dan nonverbal untuk mencapai tujuan tertentu.

Komunikasi bisnis adalah pertukaran gagasan atau pendapat, informasi, instruksi yang meiliki tujuan tertentu yang disajikan secara personal atau interpersonal melalui simbol-simbol atau sinyal untuk mencapai efektifitas atau efesiensi produk kerja di dalam struktur jenjang atau level dan sistem organisasi yang kondusif yaitu agar pihak mengerti dan tahu, tetapi harus jugalah persuasif, agar pihak lain bersedia menerima suatu paham atau keyakinan untuk melakukan suatu perbuatan atau kegiatan.

Unsur Pokok Komunikasi Bisnis

Dalam komunikasi bisnis terdapat enam unsur pokok, yaitu:

Memiliki tujuan, artinya komunikasi bisnis harus memiliki tujuan yang telah ditetapkan sebelumnya sejalan dengan tujuan organisasi

Pertukaran, dalam hal ini melibatkan paling tidak dua orang atau lbih yakni komunikator dan komunikan.

Gagasan, opini, informasi, instruksi merupakan isi dari pesan yang bentuknya beragam tergantung tujuan, situasi, dan kondisinya.

Menggunakan saluran personal atau impersonal yang mungkin bersifat tatap muka, menggunakan media tertentu atau melalui media yang menjangkau jutaan orang secara bersamaan. Meggunakan simbol atau sinyal yang merupakan alat atau metode yang dapat dimengerti atau dipahami oleh penerima untuk menyampaikan pesan. Pencapaian tujuan organisasi: salah satu karakteristik yang membedakan organisasi atau lembaga formal dari informasi adalah adanya tujuan yang telah ditetapkan sebelumnya oleh manajemen (dalamhttp://forzainterkomunikasi.blogs pot.co.id/2012/10/pengertian-komunikasibisnis.html : diakses 31 maret 2017)

$$
\text { Untuk dapat mengembangkan }
$$

kemampuan dalam berkomunikasi secara efektif, baik secara personal maupun professional paling tidak kita harus menguasai empat jenis keterampilan dasar dalam berkomunikasi, yaitu : menulis, membaca, berbicara dan mendengar.

Dari pendapat tersebut dapat disimpulkan bahwa Unsur yang paling penting dalam berkomunikasi adalah bukan sekedar apa yang kita tulis atau yang kita katakan, tetapi karakter kita dan bagaimana kita menyampaikan pesan kepada penerima pesan. Penerima pesan tidak hanya sekedar mendengar kalimat yang disampaikan tetapi juga membaca dan menilai sikap kita. Jadi syarat utama dalam komunikasi yang efektif adalah karakter kokoh yang dibangun dari fondasi etika serta integritas pribadi yang kuat. 


\section{PENGERTIAN BERWIRAUSAHA}

MOTIVASI

Motivasi adalah keadaan dalam pribadi seseorang yang mendorong keinginan individu untuk melakukan kegiatan-kegiatan tertentu guna mencapai tujuan (Handoko, 2003). Selain itu menurut Siswanto (2003) mengartikan motivasi sebagai keadaan kejiwaan atau menggerakkan dan mengarah atau menyalurkan perilaku kearah pencapaian kebutuhan yang memberi kepuasan atau mengurangi ke tidak seimbangan

Lain halnya dengan Stevenson (2001) yang mendefinisikan motivasi sebagai insentif, dorongan, atau stimulus untuk bertindak dimana motivasi adalah semua hal verbal, fisik atau psikologis yang membuat seseorang melakukan sesuatu sebagai respon.

Menurut Sardiman (2008:73) Motivasi adalah energi dalam diri seseorang yang ditandai dengan munculnya "feeling" dan didahuluidengan tanggapan terhadap adanya tujuan.

Motivasi terbagi atas 3 jenis, yaitu Fear Motivation adalah motivasi yang didorong oleh ketakutan. Achievement Motivation adalah motivasi yang didorong oleh keinginan mencapai sesuatu ,Inner Motivation adalah motivasi yang didasarkan oleh misi tujuan hidupnya. Dari ketiga jenis tersebut yang paling baik adalah dalam berwirausaha Achievment Motivation.

Motivasi adalah suatu faktor yang mendorong seseorang untuk melakukan sesuatu perbuatan atau kegiatan tertentu, sehingga motivasi dapat diartikan sebagai pendorong perilaku seseorang. Motivasi orang melakukan bisni wirausaha sering berbeda. Keanekaragaman ini menyebabkan perbedaan dalam perilaku yang berkaitan dengan kebutuhan dan tujuan.Dari pendapat di atas dapat disimpulkan bahwa fungsi sumber belajar adalah untuk membantu siswa dalam memperjelas bahan pelajaran dan menambah pengetahuan. Fungsi-fungsi di atas sekaligus menggambarkan tentang pentingnya kelengkapan sumber belajar untuk kepentingan proses dan pencapaian hasil pembelajaran siswa.

\section{MINAT BERWIRAUSAHA}

Minat berwirausaha

adalah

kecenderungan atau gejala yang menunjukkan seseorang tertarik, senang pada dunia wirausaha. Seorang mahasiswa berminat berwirausaha
NIAGAWAN Vol 7 No 1 Maret 2018

karena mahasiswa tersebut mempunyai pengalaman yang menyenangkan sehingga ingin dapat terus terlibat dalam kegiatan kewirausahaan. Hal ini sesuai dengan pendapat Buchari Alma (2006: 5-6) bahwa:

Faktor yang mendorong minat berwirausaha adalah lingkungan yang banyak dijumpai kegiatan-kegiatan berusaha, guru sekolah dan sekolah yang mengajarkan kewirausahaan, teman pergaulan, lingkungan famili, sahabat yang dapat diajak berdiskusi tentang ide wirausaha, pendidikan formal, pengalaman bisnis kecilkecilan.

Minat dalam diri seseorang dapat tumbuh dan berkembang sesuai dengan faktorfaktor yang mempengaruhinya. Menurut Suryana (2003: 47) faktor-faktor yang mempengaruhi keinginan seseorang untuk berwirausaha adalah faktor pribadi dan faktor lingkungan. Faktor pribadi dan faktor lingkungan menjadi faktor yang kuat untuk mempengaruhi seseorang agar tertarik terjun dalam dunia wirausaha. Hal ini sesuai dengan pendapat Kir Haryana (1995:10) minat seseorang terjun ke bidang wirausaha dapat dipengaruhi oleh banyak faktor yaitu faktor dari dalam diri dirinya (intern) yang terdiri dari faktor bakat, kepribadian, serta kemampuan maupun faktor dari luar dirinya (faktor ekstern) yaitu sarana prasarana, pendidikan, dan lingkungan sosial.

\section{FAKTOR PENDORONG MINAT BERWIRAUSAHA}

Bygrave (Buchari Alma, 2013: 11) membagi faktor pendorong berwirausaha antara lain:

1. Faktor personal, menyangkut aspek kepribadian diantaranya:
a. Adanya ketidakpuasan terhadap pekerjaan seseorang
b. Adanya pemutusan hubungan kerja, tidak ada pekerjaan lain
c. Dorongan karena faktor usia
d. Komitmen/minat tinggi pada bisnis

2. Faktor Environment, menyangkut hubungan dengan lingkungan fisik

a. Adanya persaingan dalam dunia kehidupan

b. Adanya sumber-sumber yang bisa dimanfaatkan seperti modal, tabungan, warisan, bangunan, dan lokasi strategis

c. Mengikuti latihan kursus bisnis atau incubator bisnis 
d. Kebijaksanaan pemerintah, adanya kemudahan lokasi berusaha, fasilitas kredit dan bimbingan usaha.

3. Faktor Sosiological, menyangkut hubungan dengan famili dan sebagainya

a. Adanya hubungan-hubungan atau relasi bagi orang lain

b. Adanya tim yang dapat diajak kerja sama dalam berusaha

c. Adanya dorongan dari orangtua untuk membuka usaha

d. Adanya bantuan famili dalam berbagai kemudahan

e. Adanya pengalaman bisnis sebelumnya

Minat berwirausaha dapat muncul dalam diri seseorang karena dipengaruhi oleh beberapa faktor, menurut Zimmerer dan Scarborough (1998: 76) faktor-faktor yang mempengaruhi keberhasilan seseorang dalam berwirausaha adalah motivasi dalam diri masing-masing individu maupun dari orang lain, pengalaman, serta pendidikan. Seseorang mulai berminat terhadap suatu hal biasanya ditunjukkan dengan suatu pernyataan yang menunjukkan seseorang lebih tertarik pada suatu obyek dan melalui partisipasi dalam suatu aktivitas. Seseorang yang tertarik dan senang pada suatu usaha akan menunjukkannya dalam kegiatan mempelajari, memahami, dan berkecimpung dalam usaha itu. Seseorang yang berminat dalam dunia wirausaha akan merasa senang melakukan berbagai tindakan yang berhubungan dengan wirausaha. Minat bersifat pribadi, untuk itu minat antara individu satu dengan individu yang lain berbeda. Jadi minat berwirausaha dapat dipengaruhi oleh beberapa faktor, yaitu bakat, kepribadian, kemampuan diri, sarana prasarana, pendidikan, lingkungan sosial, motivasi, pengalaman.

$$
\text { Ating Tedjasutisna (2004: 23) }
$$

mengatakan bahwa "hal yang mendorong seseorang berminat dan mau berwirausaha adalah adanya sifat penasaran, keinginan menanggung resiko, faktor pendidikan, dan faktor pengalaman para siswa sendiri". Seseorang yang memiliki rasa penasaran yang tinggi akan mencoba untuk bertindak sehingga rasa penasarannya terpecahkan, hal itu dapat diterapkan dalam kegiatan wirausaha. Seseorang yang penasaran dengan dunia wirausaha akan berusaha menekuni atau melakukan kegiatan kewirausahaan. Seseorang yang memiliki jiwa kewirausahaan akan tertarik untuk berwirausaha karena tertarik dengan tantangan yang ada didalamnya, yaitu tantangan menanggung resiko kegagalan.

Dari uraian diatas dapat disimpulkan bahwa minat berwirausaha adalah suatu gejala atau kecenderungan yang menunjukkan perasaan senang, ketertarikan, kemauan untuk terlibat dalam kegiatan wirausaha, pemusatan perhatian dan

\section{METODE PENELITIAN}

\section{Lokasi dan Waktu Penelitian}

Penelitian ini dilaksanakan di Medan tepatnya di Fakultas Ekonomi Universitas Negeri Medan tahun pelajaran 2017/2018 yang beralamat di Jalan Willem Iskandar Pasar V Medan.

\section{Populasi dan Sampel}

Dalam penelitian ini populasi yang diambil adalah seluruh mahasiswa Pendidikan Tataniaga Fakultas Ekonomi Unimed Stambuk 2013.Di dalam penelitian ini jumlah populasi lebih dari 100, maka berdasarkan ketentuan tersebut di atas, penulis mengambil sampel sebanyak $75 \%$ dari jumlah populasi yaitu sebanyak 81 orang dengan simple random sampling (acak sederhana).

\section{DEFINISI OPERASIONAL}

a. Mata Kuliah Komunikasi bisnis adalah mata kuliah yang mempelajari bagaimana cara berkomunikasih yang baik dan benar ketika melaksanakan kegiatan bisnis selain itu, pengetahuan-pengetahuan tentang pertukaran gagasan atau pendapat, informasi, instruksi yang memiliki tujuan tertentu yang disajikan secara personal atau interpersonal melalui simbol-simbol atau sinyal untuk mencapai efektifitas atau efesiensi produk kerja. Dengan indikator Nilai Mata Kuliah Komunikasi Bisnis Mahasiswa (DPNA)

b. Motivasi berwirausaha dapat muncul dalam diri seseorang karena adanya dorongan untuk mencapai kesuksesan dalam bidang kewirausahaanMotivasi yang tinggi pada seseorang untuk sukses dalam bidang kewirausahaan akan memunculkan minat berwirausaha pada diri seseorang yang dapat dilihat pada indikator mendapat laba,kebebasan impian personal/aktualisasi diri, kemandirian, kebutuhan fisiologis, rasa aman, dan kebutuhan social dan prestasi

c. Minat berwirausaha adalah kecenderungan atau gejala yang menunjukkan seseorang tertarik, senang pada dunia wirausaha. Faktor pendorong yang mempengaruhi seseorang terjun dalam dunia wiarusaha yang terdiri dari indikator faktor personal (menyangkut aspek kepribadian), faktor environment (menyangkut hubungan dengan 
lingkungan fisik), dan faktor sosiological (menyangkut dengan famili dan sebagainya)

\section{Teknik Analisis Data}

Perhitungan Regresi Linear Berganda

Untuk mengetahui pengaruh $\mathrm{X}_{1}$ dan $\mathrm{X}_{2}$ terhadap $\mathrm{Y}$ digunakan rumus regresi berganda dengan rumus:

$$
Y=a+b_{1} X_{1}+b_{2} X_{2} \text { (Sugiyono, 2010: 267) }
$$

\section{Pengujian Hipotesis Secara Parsial (Uji t)}

Uji t atau parsial digunakan untuk menguji apakah variabel bebas $\left(\mathrm{X}_{1}, \mathrm{X}_{2}\right)$ mempunyai pengaruh secara parsial terhadap variabel terikat. Maka digunakan uji $\mathrm{t}$ dengan menggunakan rumus sebagai berikut:

$t_{\text {hitung }}=\frac{b i(\beta i)}{S E(\beta i)}$

\section{Pengujian Hipotesis Secara Simultan (Uji F)}

Untuk menguji hipotesis secara simultan digunakan rumus:

$F_{h}=\frac{R^{2} / k}{\left(1-R^{2}\right) /(n-k-1)} \quad$ (Sugiyono, 2010: 266)

\section{Menguji Koefisien Determinasi $\left(\mathbf{R}^{2}\right)$}

Koefisien determinasi memberikan proporsi atau persentase variabel total dalam variabel $\mathrm{Y}$ yang dijelaskan oleh model regresi. Nilainya berkisar antara 0 sampai 1 . Nilai $R^{2}$ yang kecil berarti kemampuan variabel-variabel bebas dalam menjelaskan variabel tidak bebas amat terbatas. Nilai koefisien yang mendekati 1 , berarti modelnya sudah sesuai untuk menjelaskan hubungan antara variabel bebas dengan variabel terikat.

$R^{2}=\frac{J K R}{J K T} \times 100 \%$

\section{HASIL DAN PEMBAHASAN}

\section{Pengaruh Mata kuliah Komunikasi Bisnis} Terhadap Minat Berwirausaha

Berdasarkan hasil penelitian yang telah dilakukan di Pendidikan Tataniaga Fakultas Ekonomi Unimed dengan jumlah sampel sebanyak 81 mahasiswa maka diperoleh persamaan regresi pada analisis regresi linear berganda yaitu $\mathrm{Y}=27,345+0,517 \mathrm{X} 1+0,041 \mathrm{X} 2$. Pada uji hipotesis secara parsial (Uji t) variabel mata kuliah Komunikasi Bisnis (X1) memperoleh nilai t_hitung > t_tabel $(6,846>$ 1,664) . Berdasarkan hasil tersebut maka dapat diketahui bahwa variabel Komunikasi bisnis (X1) berpengaruh Positif terhadap Minat Berwirausaha mahasiswa (Y).

\section{NIAGAWAN Vol 7 No 1 Maret 2018}

Dalam penelitian ini mata kuliah Komunikasi Bisnis mahasiswa dapat dilihat dari nilai yang diperoleh mahasiswa dari dosen mata kuliah komunikasi bisnis. Mata Kuliah Komunikasi bisnis adalah mata kuliah yang mempelajari bagaimana cara berkomunikasi yang baik dan benar ketika melaksanakan kegiatan bisnis, maka berdasarkan hasil penelitian ini dapat disimpukan bahwa semakin baik nilai mata kuliah Komunikasi bisnis maka semakin berpengaruh terhadap minat berwirausaha mahasiswa.

\section{Pengaruh Motivasi Berwirausaha}

Berdasarkan hasil penelitian yang telah dilakukan di Pendidikan Tataniaga Fakultas Ekonomi Unimed dengan jumlah sampel sebanyak 81 mahasiswa maka diperoleh persamaan regresi pada analisis regresi linear berganda yaitu $\mathrm{Y}=27,345+0,517 \mathrm{X} 1+0,041 \mathrm{X} 2$. Pada uji hipotesis secara parsial 1 (Uji t) variabel Motivasi Berwirausaha (X2) memperoleh nilai t_hitung < t_tabel $(0,619<1,664)$, berdasarkan hasil tersebut maka dapat diketahui bahwa, variabel motivasi berwirausaha (X2) tidak berpengaruh terhadap minat berwirausaha mahasiswa (Y).

Hasil ini tidak sesuai dengan penelitian sebelum nya yang dilakukan oleh Ari (2015) Berdasarkan analisis regresi sederhana diperoleh koefisien korelasi sebesar 0,313 yang berarti korelasinya positif. Harga koefisien diterminasi sebesar 0,098 yang berarti bahwa motivasi berwirausaha memberikan pengaruh sebesar 9,8\% terhadap minat berwirausaha mahasiswa. Hasil thitung sebesar 2,966 lebih besar dari ttabel yang berarti signifikan. Berdasarkan hal tersebut dapat disimpulkan bahwa motivasi berwirausaha berpengaruh positif dan signifikan terhadap minat berwirausaha mahasiswa Program Studi Pendidikan Administrasi Perkantoran Fakultas Ekonomi Universitas Negeri Yogyakarta

Setelah diteliti, hasilnya tidak berpengaruh, maka artinya adalah data yang dikumpulkan tidak berhasil membuktikan keterkaitan antara X2 dengan $\mathrm{Y}$, dan bukan berarti X2 tidak berpengaruh terhadap $\mathrm{Y}$, Melainkan data sampel tidak berhasil membuktikan hubungan tersebut. Dalam arti, variabel ini masih memiliki peluang untuk dapat memiliki pengaruh jika diteliti dengan sampel yang berbeda 
Pengaruh Mata Kuliah Komunikasi Bisnis Dan Motivasi Berwirausaha Terhadap Minat Berwirausaha

Berdasarkan hasil penelitian yang telah dilakukan di Pendidikan Tataniaga Fakultas Ekonomi Unimed dengan jumlah sampel sebanyak 81 mahasiswa maka diperoleh diperoleh nilai nilai $F_{-}$(Hitung )sebesar 40,501 dengan nilai signifikansi 0,000 . Sedangkan nilai F_(tabel ) pada derajat kebebasan df (N1) sebesar 3,11. Dapat disimpulkan F_(Hitung )> F_Tabel $(40,501>3,11)$ dan nilai signifikansi lebih kecil dari taraf signifikansi $\alpha<0,05(0,000$ $<0,05)$.

Koefesien determinasi ( $\mathrm{R}$ square) juga bernilai 0,509 atau dengan kata lain nilai koefesien determinasinya adalah sebesar 0,509 $\mathrm{X} 100 \%=50,9 \%$. Dari data tersebut maka dapat kita tarik kesimpulan bahwa dalam penelitian ini variabel mata kuliah Komunikasi bisnis (X1) dan Motivasi Berwirausaha (X2) memberikan sumbangan pengaruh sebesar 50,9\% terhadap Minat Berwirausaha (Y) dan sisanya yaitu sebesar 49,1\% disumbangkan oleh faktor lain diluar dari penelitian ini.

Maka dapat ditarik kesimpulan bahwa mata kuliah komunikasi bisnis dan motivasi berwirausaha secara bersama-sama memiliki pengaruh terhadap minat berwirausaha mahasiswa. Dimana, semakin tinggi pengetahuan mahasiswa di mata kuliah komunikasi bisnis dan semakin tinggi motivsi berwirausaha mahasiswa, maka akan semakin baik pula Minat berwirausaha mahasiswa pendidikan tataniaga stambuk 2013 UNIMED.

\section{KESIMPULAN DAN SARAN}

Berdasarkan hasil pengujian yang telah dilakukan dalam penelitian ini, maka diperoleh kesimpulan sebagai berikut :

Berdasarkan hasil regresi linear berganda di atas terdapat nilai konstanta (a) sebesar 27,435, artinya jika variabel X1 dan X2 sebesar nol, maka Minat Berwirausaha mahasiswa (Y) adalah sebesar 27,435. Selanjutnya untuk nilai koefesien regresi variabel X1 (b1) sebesar 0,517. Artinya jika variabel X1 mengalami kenaikan sebesar satuan dan variabel independen lainya bernilai tetap, maka Minat Berwirausaha mahasiswa (Y) mengalami penurunan sebesar $51,7 \%$. Sementara itu, nilai koefesien regresi variabel X2 (b2) terdapat nilai sebesar 0,041. Artinya jika variabel X2 mengalami kenaikan sebesar satuan dan variabel independen lainya
NIAGAWAN Vol 7 No 1 Maret 2018 bernilai tetap, maka pola Minat Berwirausaha (Y) mengalami kenaikan sebesar $41 \%$.

Ada pengaruh positif dan signifikan antara mata kuliah Komunikasi Bisnis terhadap Minat berwirausaha mahasiswa Pendidikan Tataniaga Fakultas Ekonomi Unimed Stambuk 2013. Hal tersebut dapat dilihat dalam uji $\mathrm{t}$ dimana nilai t_hitung < t_tabel $(6,846>1,664)$ dengan nilai signifikansi lebih kecil dari taraf signifikansi $0,05(0,000<0,05)$.

Tidak ada pengaruh positif dan signifikan antara Motivasi Berrwirausaha terhadap Minat Berwirausaha mahasiswa Pendidikan Tataniaga Fakultas Ekonomi Unimed Stambuk 2013. Hal tersebut dapat dilihat dalam uji $\mathrm{t}$ dimana nilai Untuk Motivasi Berwirausaha (X2) t_hitung sebesar 0,619 dengan nilai signifikan sebesar 0,537. Sedangkan nilai t_tabel sebesar 1,664. Maka dari hasil tersebut kita dapat melihat bahwa nilai t_hitung $<$ t_tabel $(0,619<1,664)$ dengan nilai signifikansi lebih besar dari taraf signifikansi $0,05(0,537>0,05)$.

Ada pengaruh positif dan signifikan antara mata kuliah Komunikasi Bisnis dan Motivasi Berwirausaha terhadap Minat berwirausaha mahasiswa Pendidikan Tataniaga Fakultas Ekonomi Unimed Stambuk 2013. Hal tersebut diperoleh berdasarkan hasil uji f secara simultan dengan nilai F_(Hitung )> F_Tabel (40,501 > 3,11 ) dan nilai signifikansi lebih kecil dari taraf signifikansi $\alpha<0,05(0,000<0,05)$.

Maka, mata kuliah Komunikasi bisnis (X1) dan Motivasi Berwirausaha (X2) memberikan sumbangan pengaruh sebesar 50,9\% terhadap Minat Berwirausaha (Y) dan sisanya yaitu sebesar 49,1\% disumbangkan oleh faktor lain diluar dari penelitian ini.

\section{REFERENSI}

Aflit Nuryulia Praswati (2014) Analisis FaktorFaktor Yang Mempengaruhi Minat Wirausaha Di Kalangan Mahasiswa Studi Kasus: Fakultas Ekonomi Dan Bisnis Universitas Muhammadiyah Surakarta ISBN : 134-142 diakses tanggal 1 mei 2017

Arikunto, Suharsimi. 2006. Prosedur Penelitian Secara Pendekatan Praktik. Jakarta : PT. Rineka Cipta

Asep, Hermawan. (2005). Penelitian Bisnis Paradigma Kuantitatif. Jakarta: Grasindo

Ating, Tedjasutisna. (2004). Memahami Kewirausahaan SMK Tingkat 1. Bandung: Armindo 
Bambang Satrionugroho dan Didit Nugroho (2015) Analisa Pengaruh Matakuliah Kewirausahaan Terhadap Minat Wirausaha Mahasiswa Stmik Sinar Nusantara ISSN : 1693 - 1173 diakses tanggal 1 mei 2017

Alma, Buchari (2013). Kewirausahaan untuk Mahasiswa dan Umum. Bandung: Alfabeta

Bukirom, dkk (2014) Pengaruh Pendidikan Berwirausaha Dan Motivasi Berwirausaha Terhadap Pembentukan Jiwa Berwirausaha Mahasiswa ISSN : 0851442 diakses tanggal 1 mei 2017

Fariq, Iqbal , Unsur Komunikasi Bisnis http://forzainterkomunikasi.blogspot.co.id (31 maret 2017)

Hisrich, dkk (2005). Entrepreneurship Edisi 7. New York: McGraw-Hill Companies, Inc

Hanum, (2014) Analisis Pengaruh Faktor Internal dan Faktor Lingkungan Eksternal terhadap Minat Berwirausaha (Studi pada siswa SMA Negeri 1 Semarang). Medan. Skripsi: Fakultas Ekonomika dan Bisnis Universitas Diponegoro Semarang

Jamal Ma'mur Asmani. (2011). Sekolah Entrepreneur. Yogyakarta: Harmoni

Kasmir. (2006). Kewirausahaan. Jakarta: Raja Grafindo Persada

Kir, Haryana. (1995). Wawasan dan Gagasan Kewiraswastaan dan Berwirausaha. Yogyakarta: FPIPS IKIP Yogyakarta

Saiman,leonardus (2009). Kewirausahaan, Teori, Praktik, dan Kasus-kasus. Jakarta: Salemba Empat

Wiratmo,Mansyukur (2009). Pengantar Kewirauswastaan Kerangka Dasar Memasuki Dunia Bisnis, Yogyakarta: BPFE

Purwanto,Djoko (2013). Komunikasi Bisnis Edisi 4, Jakarta: Erlangga

Fajar,Sakti (2014) Pengaruh Kemandirian Dan Motivasi Berwirausaha Terhadap Minat Berwirausaha Siswa Smkn 1 Seyegan Education Jurnal 185-186 diakses tanggal 1 mei 2017

Ullen,Yuliana (2015) Strategi Komunikasi Bisnis PT Alif Persada Nusantara dalam meningkatkan penjualan Garden Hills Estate 2013 ISSN : 134144 diakses tanggal 1 mei 2017

Siswadi,Yudi (2013) Analisis Faktor Internal, Faktor Eksternal Dan Pembelajaran
NIAGAWAN Vol 7 No 1 Maret 2018

Kewirausahaan Yang Mempengaruhi Minat Mahasiswa

Sudjana, Ibrahim, (2009). Penelitian dan Penilaian Pendidikan. Bandung : Sinar Baru Algensindo.

Sugiono. 2010. Metode Penelitian Pendidikan. Bandung: Alfa 